\title{
IFRS ADOPTION AND STOCK PRICE DELAY: THE CASE OF ROMANIA
}

\author{
Andra Maria ACHIM (NASCA $)^{1}$ \\ Adriana TIRON-TUDOR ${ }^{2}$
}

\begin{abstract}
The International Financial Reporting Standards (IFRS) are gaining more and more importance at the global level and determine a series of changes in the national economies. The intended benefits of the IFRS adoption consists in increasing the comparability and transparency of the financial reporting, reducing information asymmetry in capital markets, attracting foreign capital and decreasing the cost of capital. The aim of this research is to assess whether there is any impact of the IFRS adoption upon the informational efficiency of the Romanian stock market. We quantify the informational efficiency of the stock market through the stock price delay. Starting from 2012, all the Romanian listed companies on Bucharest Stock Exchange should report their individual financial statements using IFRS. We divide the time horizon into two sub-periods: ex-ante (2005-2010) and expost (2011-2014) IFRS adoption. This way we can capture the impact of IFRS adoption on the behavior of the stock prices. Using econometric models, we test if the IFRS adoption has caused some changes in the incorporation of the available information into the stock prices. The results show that the stock price delay is greater in the post-adoption period, as compared to the pre-adoption period. We conclude that IFRS adoption in Romania had a negative influence on the incorporation of information into stock prices. The results of our study might be of great interest to the policy standard setters as these organizations can define and learn from the policies adopted and applied.
\end{abstract}

Keywords: IFRS adoption, stock price delay, capital market, informational efficiency, financial reporting, accounting quality.

JEL Classification: M41, M48

\section{Introduction}

Common sense tells us that the accounting information is relevant for the valuation of assets (Brennan, 1991). In other words, it is self-understood that the accounting information is extremely important for the capital market, thus contributing to the informational efficiency of it. The investors and the actors of the capital market spend large sums of money in order to obtain accounting information, which they analyze and help them to make forecasts on the results of the companies traded on the capital market. These forecasts influence the investment decisions of the participants in the financial market. At the same time, the accounting results of the companies influence the evolution of the securities' prices. With the publication of the financial statements of the companies, a series of changes in stock prices takes place, depending on the performances obtained by the companies. So, at first sight, we can state that the accounting data influence the capital market.

International Financial Reporting Standards are a set of high-quality accounting standards used in order to improve and uniformize the financial reporting. Under IFRS, accounting data is more easily comparable and harmonized. IFRS are globally used, the number of states that comply with and adopt IFRS continues to grow every year. Also, the adoption of IFRS impacts various sectors, such as

\footnotetext{
${ }^{1}$ Babes-Bolyai Unversity, Faculty of Economic Studies and Business Administration, Cluj-Napoca, Romania, E-mail: andra.achim@econ.ubbcluj.ro

${ }^{2}$ Babeş-Bolyai Unversity, Faculty of Economic Studies and Business Administration, Cluj-Napoca, România.

DOI: 10.29302/oeconomica.2018.20.2.3
} 
financial reporting, foreign investment, capital allocation, accounting policies, economic growth. The research results at international level show that, in general, the quality of financial information has

increased after IFRS adoption. De George, Xi \& Lakshmanan (2016) consider that if we had to sum up the development of the IFRS literature, most of the early studies paint IFRS as significantly benefiting adopting firms and countries in terms of improved transparency, lower costs of capital, improved cross-country investments, better comparability of financial reports and increased following by foreign analysts. Also, the share prices have become more correlated with the accounting data, analysts' forecast accuracy has improved and even the cost of capital has declined. However, according to Larson \& Street (2004), there are a series of institutional factors that affect primarily the level of compliance with IFRS and prevent the required benefits of IFRS from being validated. Therefore, we choose to focus on the effects of the IFRS adoption regarding capital market efficiency.

The main objective of our paper consists of the analysis of the IFRS adoption's impact on the stock prices in Romania. We want to capture the implications of the IFRS adoption concerning the informational efficiency of the stock market. The scientific research question that arises is: 'Does IFRS adoption in Romania influence the informational efficiency of the national stock market?' This study contributes to the literature by enhancing the knowledge regarding the effects of the IFRS adoption in an emergent market. Also, our study contributes to extant research by focusing on the economic consequences of policy choices in an emergent economy.

The novelty of our research consists in the analysis of the impact of the IFRS's adoption in an emergent economy. While the developed economies are intensively analyzed in the literature, as most of the studies are concentrated upon them, the studies upon emergent countries are in an incipient phase. That is why, we are motivated to analyze the case of Romania in regard to the IFRS adoption and its implications on the stock market. The papers upon the developed economies represent a trustable source of information and a guide in our research. Anyway, their results cannot be extrapolated for the emergent countries, because the institutional environment is different and sometimes not prepared for all the IFRS adoption process. Consequently, the results of the IFRS application in emergent economies could substantially differ as compared to the developed states.

The process of the IFRS adoption is influenced by the country's characteristics and institutional settings. As Turki, Wali \& Boujelbene (2017) state, the examination of the impact of IFRS, taking as sample one country, aims to eliminate any biases associated with the use of international samples and to avoid the effect of differences in institutional environments before adopting IFRS.

Efficient markets theory claims that in the case of efficient capital markets, it may be considered at any time that the price of assets fully reflects all the information available. This happens in an ideal case, but in reality, it is quite different. There are categories of users of financial information that have privileged information, which they do not reveal to the rest of the actors on the financial market, or make it public only when it is in their favour.

The management of the companies may have monopolistic access to the unrevealed information, at which the market would have reacted if it would have been made public. The management may choose in this case the moment when to disclose such information, depending on the benefits they obtain (Emery, 1974). The accounting literature suggests that the figures can be manipulated by accountants, this fact having an impact on financial statements and on the information from the capital market. The practices of income smoothing are well- known. Emery (1974) considers that the majority of the techniques of income smoothing are the result of the management's ability to alter/denature the accounting figures reported through accounting standards and applied procedures.

The efficiency of the market has been defined in various ways over the time, the literature does not offer a standard definition. The definition given by Fama (1970) is the most commonly used in the academic environment. Thus, the hypothesis of efficient markets defines a market as being efficient 
when the price of the shares reflects all the information available on the market, this meaning that all the new information is quickly incorporated into the stock price.

Lo (2008) shows that, although numerous studies have been carried out in this field, thousands of items being published on this subject, it has not yet been reached a consensus on the matter if the

financial markets are efficient. Several researchers, including Campbell et al. (1997), Lo (2008), Lo \& MacKinley (1999) claim that perfect efficiency is an abstract term, in fact, there is no such thing. They consider that it is more appropriate to speak about relative efficiency. Relative efficiency is the efficiency of a market measured by comparison with another market. In other words, it is more useful to determine the degree of efficiency than to test if the market is or is not efficient. In these circumstances, it is not surprising that, after years of empirical research, we know so little about the differences between the levels of informational efficiency of markets and about the characteristics associated with higher levels of informational efficiency.

Our research is a single case study analysis and it is conducted using quantitative and empirical analysis accordingly to the research methodology. Among the measures that can be used to determine the informational efficiency of capital markets, we use the delay of the incorporation of information in prices. The speed of information incorporation is a central topic of the efficiency of the markets, due to the fact that an efficient market is characterized as one in which stock prices respond instantaneously to the arrival of new information (Lim \& Hooy, 2010). Hou \& Moskowitz (2005) have developed a measure that captures the average delay with which the stock price of a share responds to the new information available on the market. The authors use regression of weekly stock returns of companies against the market indexes (local and global). This measure is often encountered in the studies in this field. Bae et al. (2012) use this measure because they consider that it quantifies the variation of stock return explained by global /local market index, depending on the case.

Our findings show that the adoption of IFRS in Romania had a negative impact on the incorporation of new information into the stock price. The stock price delay is greater in the period after the adoption of IFRS, as compared to the period before this change in the accounting environment. This fact is intriguing, as we were tempted to assume, based on previous studies, that the incorporation of information into stock prices increases after the adoption of IFRS. As Romania is an emergent economy and the studies upon emerging economies are few, we can say that our research brings important contribution in this field.

The remainder of the paper is organised as follows. Section 1 offers a view of the current state of the literature regarding the analysed subject. Section 2 describes the data and the methodology of research. The results are provided in Section 3 and in the end, we present some concluding remarks and observations on possible future research.

\section{Literature Review}

Economic literature suggests that the adoption of IFRS generally improves the level of information disclosure, as well as the quality and comparability of financial reporting practices. IFRS adopters are expected to enjoy the foregoing benefits of this process (Sato \& Tekeda, 2017). Many proponents believe that IFRS reporting is of higher quality than previous local GAAP and that its adoption improves financial transparency, lowers information asymmetry in capital markets, promotes cross-border comparability, attracts foreign capital and consequently lowers the cost of capital for firms in adopting countries (De George). However, some studies argue that the economic benefits of IFRS adoption depend on the institutional environment of the adopting countries in the way that more developed countries possess stronger economic and legal environments that enhance the application of the IFRS. Several researchers have provided evidence that positive effects appear especially in countries with strongly enforces laws and regulations (Daske et al., 2008; Armstrong et al., 2010; Landsman et al., 2012). 
The accounting figures reported by any company are one of the most important sources of information for investors' decisions based on stock prices (Breton \& Taffler, 1995). FASB claims that one of the principal aims of accounting is to inform investors about the matters that can help them in anticipating future economic events which are relevant for firm valuation. To achieve this objective, the accounting data should reflect the economic phenomena underlying them. Only then they can

serve to stock prices' formation and can guide the efficient allocation of capital in the economy (Novak, 2008).

Ball \& Brown (1968) are the first who analyse empirically the relationship between the accounting results and stock prices. They investigate the usefulness of the accounting data via the information content and their timeliness, and they reach the conclusion that the efficiency of the capital market is determined by appropriate sources of data, of which the annual reports of the companies represent the most important. Thus, financial data and the choice of accounting policies prove to be important in the process of price formation on the capital market.

Accounting may fail in the presentation of useful information from several causes: it can be prejudiced, handled or information is not disclosed in good time. Sometimes, because not all the criteria imposed by the regulatory bodies in the field of accounting are met, it may happen that the financial data not to capture some important economic aspects. Furthermore, the various categories of users of accounting information may require a compromise as regards the requirements of various and sometimes conflicting financial reporting (Holthausen \& Watts, 2001). In this case, the recognition of income and assets tend to be conservative. While the expected future losses must be immediately recognized in accounting, recognition of future earnings is deferred. This prudence in accounting practice is essential, representing one of the fundamental principles of accounting, but this affects the value of the earnings of a firm and its net assets (Novak, 2008).

Brennan (1991) state that there is a long history of the use of accounting data in the explanation of the relative prices of companies or in estimating the cost of capital in a given industry by the cross-section regression of prices and of the measures of the results and of the increases recorded.

One of the accounting requirements is to present information in time. Basu (1997) considers that the lack of information has more severe effects in the case of earnings, other than that of the losses. Barth et al. (2001) claim that actuality is not crucial for the usefulness of accounting information, because if the investors consider that certain aspects are particularly relevant, they will develop sophisticated techniques to forecast this information. Thus, the information in question shall be incorporated, wholly or partly, in the stock prices, before the financial reporting will officially reveal it. At the same time, the management may use techniques of manipulating the results. This may happen when someone desires to meet specific objectives, increase the stock prices or comply with the agreements with the creditors, etc. The management of results can be achieved by using opportunistic practices of adjusting the accounting methods used in determining the accrual or by temporary changes of the economic policies of the company (Roychowdhury, 2006). The manipulated results of a company may transmit misleading signals to investors about the financial position and performance of a company, and thus to produce devastating effects regarding investments.

Empirical research in the field of accounting shows that financial reporting has success in revealing useful information for the assessment of the value of a company (Novak, 2008). Thus, the accrual estimation is seen as one of the most important functions of accounting (Dechow, 1994). Investors use accounting information in their investment decisions. Of course, they pay great attention also to the non-financial data regarding companies, but the position and financial performance arising out of the reports submitted by the firms are the basis of the investment decisions.

At the same time, the capital market is based on the reliable financial information. Quality financial reporting helps the investors in the assessment of the value and performance of companies in the capital market and in making the investment decisions. The financial scandals in the United States 
of America and Europe (Worldcom, Parmalat) have highlighted the importance of the quality of the financial reporting, a focus being placed on the quality of the results (Azzali, Fornaciari \& Mazza, 2013).

Al-Htaybat (2017) studies the IFRS adoption in the case of Jordan, an emergent country, and develops an adoption model. The model illustrates the paradox of accounting changes in emerging economies, in which the actual conditions that pressure IFRS adoption are also the conditions that

prevent full adoption. As Al-Htaybat (2017) considers, emerging economies have unique features such as uncertainty and external and internal environmental pressures. All of these motivate the emergent countries toward IFRS adoption as an internationally recognized remedy and a developed high-quality solution for their accounting problems.

Determining the impact of accounting quality on the informational content of stock prices captures the way in which stock prices of the traded assets incorporate firm-specific information, in good time and in an appropriate manner. Efficient allocation of resources depends on the ability of prices to reflect all the information available at a given moment, in particular, the one specific to the firm. Yu \& Wang (2014) analyze the impact of the accounting standards on stock price informativeness in 44 countries and find a negative relationship between stock price synchronicity and the quality of the accounting standards in countries with a common-law system and with better investor protection. The results are in accordance with the theory supported by Zhang (2013), which is of the opinion that the improvement of accounting standards will lead to an increase in the welfare in general, having a positive impact on the entire society. Stock prices synchronicity is used as an inverse measure of informativeness.

The literature shows us that the accounting standards often influence the quality of the financial reporting (Barth et al., 2008; Bartov, Goldberg \& Kim, 2005). Therefore, we expect that the adoption of quality accounting standards, such as IFRS, to increase the quality of the firm-specific accounting information effectively. According to Watts \& Zimmerman (1986) and Ball (2001), the quality of the accounting information depends, among other things, on the reporting incentives granted to managers and auditors, not only on the adoption of high-quality accounting standards.

The impact of the publication of the accounting results on stock prices is studied by Ariff, Loh \& Chew (1997), which demonstrate that the unexpected changes of the results of companies are significantly associated with changes in prices on the capital market. They emphasize the idea that stock prices react to the disclosure of accounting information.

There are studies which estimate the relationship between the magnitude of the changes in the reported results and the variation in the prices on the capital market (Beaver et al., 1970; Loh \& Walter, 1986; Easton \& Harris, 1991; Strong \& Walker, 1993). Clubb (1995) concludes that the modifications of the stock prices in Great Britain are significantly influenced by the accounting results and the information disclosed on the capital market. However, Campbell et al. (1993) show that the accounting results affect stock prices and their volatility, in the case of Australia. All these studies show that unexpected changes in the accounting results produce a significant impact on the prices of securities listed on the capital market. Therefore, the connection between accounting data and the capital market is significant, the financial statements are an important source of information for the agents acting on the financial market.

Stock price delay is often studied in relation to the factors that influence the way information incorporates into the stock prices and to the speed of stock prices' adjustment to new information that appears on the market. For example, Callen et al. (2011) analyze the relationship between the poor quality of accounting information and the delay of the incorporation of information in stock prices. They follow and test the model developed by Hou \& Moskowitz (2005). The results obtained by Callen et al. (2011) suggest that the poor quality of financial reporting is expensive, as it is associated with a more significant delay of the stock price adjustment in response to the new information from the market and to a higher cost of capital. 
Theory says that in the case of perfect capital markets, without any friction, where the information is complete and investors are rational, the stock price adjusts instantaneously and completely to the new information that is revealed. In practice, however, this does not happen, because no capital market is perfect. Therefore, there are numerous studies (Barry \& Brown, 1984; Merton, 1987; Easley et al.,2002; Hou \& Moskowitz, 2005; Lambert et al., 2007) that analyze the imperfections of information, as its asymmetry and incompleteness.

Lim \& Hooy (2010) measure the speed with which the aggregate stock market in 49 countries responds to global market-wide public information. Their empirical results show that there are wide variations in the aggregate price delay values over time and across countries. The panel analysis confirms previous firm-level evidence that market size, trading volume, short sales restrictions and the degree of investability are significant determinants of price delay even at the country level.

Turki, Wali \& Boujelbene (2017) examine the relationship between the mandatory adoption of IFRS/IAS and the information content of earnings in the case of France. Based on a longitudinal study, they find evidence that for the two first years of adoption, international standards reduce significantly the cost of capital and the dispersion of the financial analysts' forecasts. Furthermore, the magnitude of this effect increases with increasing the number of years after IFRS adoption. The findings further show that the effect of IFRS adoption on financial analysts' errors is not immediate and that the errors decrease from the third year following the date of the first adoption.

Stock price delay is also studied in relation to the audit quality and state ownership. Chen et al. (2018) examine the effect of audit quality on stock price delay and whether the effect differs between two groups of Chinese firms: state-owned enterprises and non-state-owned enterprises. They find that firms with Big 4 auditors are associated with less stock price delay, this suggesting that high-quality auditors play an important role in the price formation process. Also, their study emphasizes the importance of considering the ownership type when conducting audit research.

In conclusion, the delay in the incorporation of information in prices represents an alternative to $\mathrm{R}^{2}$ of the model for the market and manages to capture the essence of the informational efficiency of capital markets.

\section{Data and Methodology}

Our objective is to determine the stock price delay on the Romanian capital market and to analyze the way the stock price responds to the new information available on the market. The stock price delay measures the speed with which local stock prices impound global information available on the market. According to Bae et al. (2012), in a well-integrated market with little friction, stock prices are expected to react to global news and information without delay. We include in our sample the shares of the companies listed on the Bucharest Stock Exchange.

We follow the model proposed by Hou and Moskowitz (2005) and then developed by Bae et al. (2012). Thus, the variable Delay is determined as follows:

\section{Delay $=1-\left(R^{2}\right.$ restricted $-R^{2}$ unrestricted $)$}

The larger the value of the delay measure, the more variation in the domestic market index returns that is explained by lagged world market returns, indicating a greater delay in the response of the aggregate stock market to the global market-wide news that has common effects across countries (Lim \& Hooy, 2010). Delay is calculated for each company listed on the BSE (Bucharest Stock Exchange), depending on the availability of financial data. 
The period of analysis is 2005-2014. We choose the time period around the year of adoption (2012) because we want to capture the impact of IFRS adoption before and immediately after the adoption date.

Of the total companies listed on the BSE, it has been eliminated those who did not have sufficient information available for this period. The information required for carrying out this study consists of the trading prices of the shares of the companies listed on the capital market in Romania. On the basis of stock prices, we determine stock returns, which are necessary for our analysis. Following this approach, 28 companies were included in our sample. The data regarding the stock prices were subtracted from the BSE website and from Thomson Reuters Eikon Database. Moreover, the sample does not contain companies that activate in the financial sector, such as insurance

companies, credit agencies and banks are excluded. This treatment is justified by the specific accounting and financial characteristics of these organisms that might bias the results (Urquiza et al., 2012).

Stock returns are calculated in the following way:

$$
R_{i, t}=\ln \left(\frac{P_{i, t}}{P_{i, t-1}}\right)
$$

Where:

$\mathrm{Ri}, \mathrm{t}=$ stock return of the share of firm $\mathrm{i}$ at time $\mathrm{t}$;

$\mathrm{Pi}, \mathrm{t}=$ stock price of the share of firm $\mathrm{i}$ at time $\mathrm{t}$;

$\mathrm{Pi}, \mathrm{t}-1=$ stock price of the share of firm $\mathrm{i}$ at time $\mathrm{t}-1$

Following the model used by Hou and Moskowitz (2005) and further developed by Bae et al. (2012), we need the values of the local and global market indexes. Thus, the local index of the capital market in Romania is the BET index, and as the global index, we use MSCI All-Country World Index obtained from Morgan Stanley Capital International. Their values are included in our database and serve to the determination of the $\mathrm{R}^{2}$ of the two equations used to calculate the variable Delay. The values of the used indexes were extracted from the Thomson Reuters Eikon Database.

The two equations, restricted and unrestricted, are presented below. For these equations, we determine the value of the $\mathrm{R}^{2}$. The dependent variable Company takes the value of weekly returns determined for each company from our sample.

$$
\begin{gathered}
\text { Restricted equation: } \\
\text { Company }=\mathrm{C}(1)+\mathrm{C}(2) * \mathrm{BET}+\mathrm{C}(3) * \mathrm{MSCI}
\end{gathered}
$$

$$
\begin{gathered}
\text { Unrestricted equation: } \\
\text { Company }=\mathrm{C}(1)+\mathrm{C}(2) * \mathrm{BET}+\mathrm{C}(3) * \mathrm{BET}(-1)+\mathrm{C}(4) * \mathrm{BET}(-2)+\mathrm{C}(5) * \mathrm{BET}(-3)+\mathrm{C}(6) * \mathrm{MSCI} \\
+\mathrm{C}(7) * \operatorname{MSCI}(-1)+\mathrm{C}(8) * \operatorname{MSCI}(-2)+\mathrm{C}(9) * \operatorname{MSCI}(-3)
\end{gathered}
$$

Regarding the variable Delay, in order to analyze it, we have chosen to divide the time horizon into the two sub-periods, pre-adoption IFRS in Romania and post-adoption IFRS in Romania, taking into account that 2012 is the year that brought the most important changes in the accounting sector for companies listed on the stock exchange. In Romania, starting with 2012, all companies listed on the capital market must prepare individual financial statements under International Financial Reporting Standards. The first year of IFRS application is 2012, but the financial statements had to be restated also for the year 2011, following IFRS. 
Therefore, we have two sub-samples, which values are compared in order to highlight any differences resulting from the application/non-application of International Financial Reporting Standards. The periods were divided as it follows:

Period pre-IFRS: 2005-2010

Period post-IFRS: 2011-2014

We study the period around the year of IFRS adoption in order to capture the effect of this change in the accounting system. We consider that the years 2011-2014 display the immediate effects of the IFRS adoption and provide evidence regarding the state of the regulations and their overall capability to encapsulate the changes.

\section{Results and Discussion}

We examine the stock price delay in the Romanian market in relation to the IFRS adoption. The two equations presented before were tested in Eviews 5.0. and the variable of interest, Delay, was annually quantified for each company. The descriptive statistics for the two sub-periods can be seen in Table 1. We notice that the average value of variable Delay is higher during the post-IFRS, this being 0,5822, in comparison with the average value during the Pre-IFRS period, 0,4218. The median follows the same trend, and it is higher for the post-IFRS, 0,5990, in relation to the period of the preIFRS, 0,3556. All these results denote that the variable Delay registers an increase in the period subsequent to the adoption of the International Financial Reporting Standards in Romania, as compared to the period before the application of these standards. Thus, we interpret that information is incorporated into stock prices in a slower manner after the adoption of IFRS.

Also, the higher is the variable Delay, the more is stock return volatility explained by the global/local indexes of the capital market. These indexes are indicators of a greater delay of the stock price in response to the new information available on the market. Therefore, in the period following the IFRS adoption, stock return volatility is better explained by the global/local index of the capital market (MSCI/BET).

Descriptive statistics of the variable Delay for the two sub-periods of an
\begin{tabular}{|c|c|c|}
\hline \multicolumn{3}{|c|}{ Variable } \\
\hline \multicolumn{3}{|c|}{ Stock Price Delay } \\
\hline Statistics & Pre-IFRS period & Post-IFRS period \\
\hline Mean & 0.4218 & 0.5822 \\
Median & 0.3556 & 0.5990 \\
Maximum & 0.9969 & 0.9975 \\
Minimum & 0.0162 & 0.0448 \\
Std. Deviation & 0.304 & 0.2886 \\
No. of observations & 167 & 112 \\
Probability & 0.0006 & 0.0127 \\
\hline
\end{tabular}

Source: compiled by authors using Eviews 5.0.

The evolution of the stock price delay in Romania is graphically shown in Figure 1, based on annual averages of the variable Delay. We notice that the trend of the stock price delay is ascending, which means that the stock price responds with a greater delay to the newly available information 
from the market, during the period of 2005-2014. This finding suggests that after IFRS adoption in Romania stock prices react to global news and information in a slower manner.

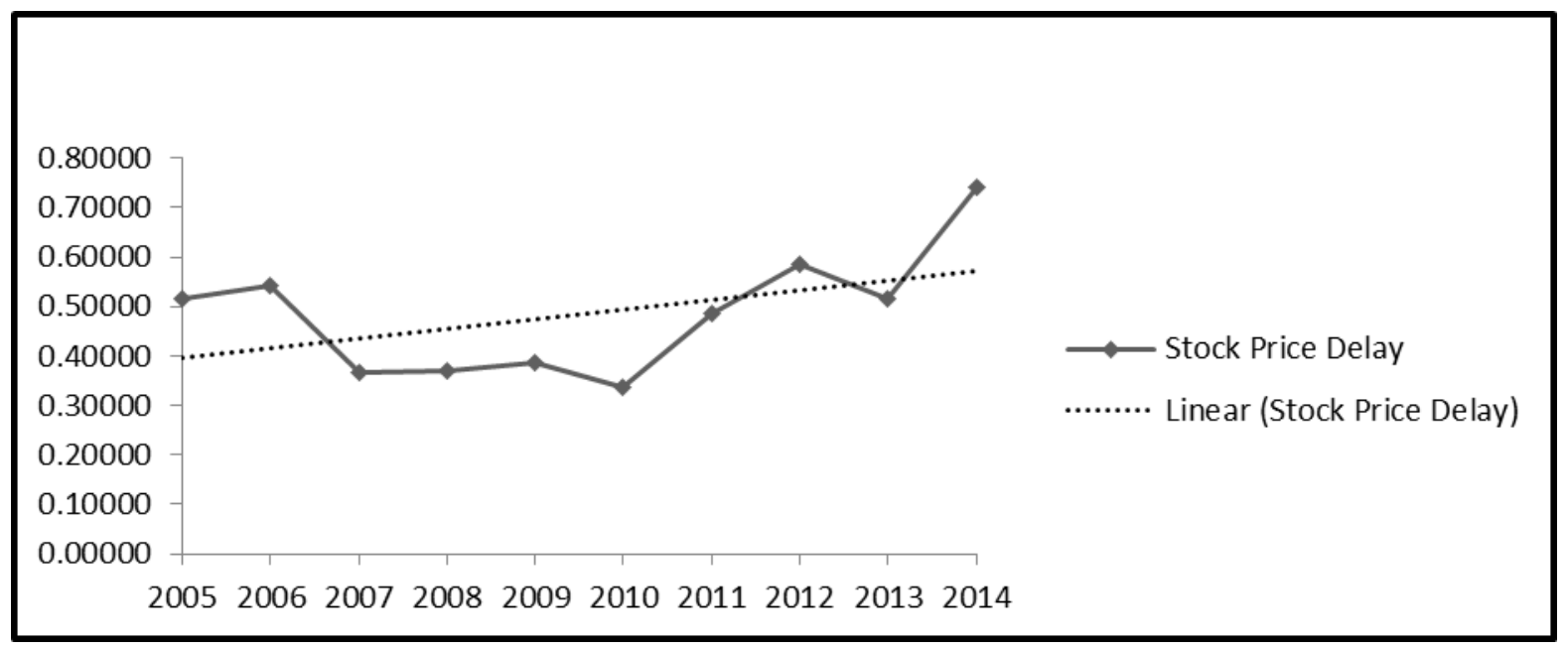

Figure no. 1 Stock Price Delay evolution in Romania

Source: compiled by authors

The results imply a decrease in the speed with which global news is impounded into stock prices and this may be explained by the level of development of the Romanian stock market, which is an emergent economy. The rules and regulations are in the process of harmonization and convergence with the international laws and practices. Moreover, the Romanian stock market is not efficient in the weak form, nor in other forms (semi-strong or strong), so we cannot state that the stock prices immediately incorporate all the information that is revealed to the market. The implications are various and this determines us to analyze the results in the whole context. Even though the results of our study show that the IFRS produce no positive impact upon the process of price's formation in Romania, the results are also influenced by external factors, others than the simple adoption of IFRS (market development, the legal system, accounting professionals' knowledge). All of these should be taken into consideration when explaining the outcomes. Our results can be corroborated with the findings of Callen et al. (2011) who discover that poor accounting quality is associated with delayed price adjustment to information. As we find no improvement in the stock price delay after the IFRS adoption, we may assume that the IFRS were not entirely absorbed in the years after the adoption or the legal and market environment were not completely prepared for this change. The Romanian stock market is not efficient in weak form, fact that was previously demonstrated, so the obtained results might have been affected by this aspect, as the stock market does not fully and rapidly incorporate all the newly available information.

\section{Conclusions}

The results of this study reveal an exciting situation regarding stock price delay in the case of Romania. Although we would have expected that the variable Delay to record a decrease in the period after the adoption of IFRS, things happen in exactly the opposite way. To sum up, we can affirm that the adoption of IFRS had not a positive impact on the incorporation of new information into the stock price. Indeed, Romania is an emergent economy and cannot be compared with the developed countries that were intensively studied in the literature and where the adoption of IFRS generally has been proven to determine the increase in the speed of the stock prices' reaction to the new information available on the market.

In other words, the adoption of IFRS in Romania makes things difficult from the point of view of the incorporation of information in stock prices. The prices respond with a greater delay to the 
changes from the capital market, as compared with their reaction prior to the adoption of IFRS. If we were to ask ourselves why this happens, one of the possible answers would consist in the fact that the new rules could be blurred for their users or could be sometimes difficult to understand.

However, the results of our study might be of great interest to the policy standard setters as these organizations can define and learn from the policies adopted or applied. Our results provide evidence relevant to the continue debate about the advantages and disadvantages of international accounting harmonization. We agree with Turki, Wali \& Boujelbene (2017), who state that even if the adoption of IFRS is mandatory since 2005 for all listed European companies, the impact of these standards may be dependent on the specific institutional factors in each country. This study can be enriched by the inclusion of several European emergent countries to clearly identify the impact of institutional environments.

The originality of this study consists in analyzing the impact of mandatory IFRS adoption on the stock price delay by dividing the analyzed period into two sub-periods, in order to catch up the effect of the change in the accounting system produced by the IFRS adoption.

One limit of our research is the reduced sample, as our study is concentrated on only one country. Anyway, this fact does not influence the importance of the results. As we have stated in the introduction, our paper represents a single case study analysis concentrated upon Romania. However, the research can be replicated on any other country. It would be interesting to study other emergent countries and to compare the results, considering the particular facts of each economy.

Another limit of research lies in the time horizon, which is small. In the future, a direction of research may be represented by widening this time horizon, especially the one after IFRS adoption, in order to see if the results do maintain, the trend of the variable Delay being ascendant. Typically, we would be tempted to believe that things change, probably influenced in the years immediately after the adoption of the IFRS by some blurriness in their application and resistance to change.

The results must be corroborated with other results of similar studies carried out on other capital markets. It is possible that the stock market of Romania to be an atypical one, due to the fact that this is not an informationally efficient market. The weak form of informational efficiency in Romania was previously tested (Todea, 2002; Dragota \& Mitrica, 2004; Stanculescu \& Mitrica, 2012; Dima \& Milos, 2006), the results showing that the weak form of informational efficiency does not characterize the Romanian capital market. By default, for this reason, the other two forms of efficiency are excluded.

Therefore, it is possible that this lack of informational efficiency to affect the results of our study. In the future, we want to replicate the study on other similar markets from Central and Eastern Europe, in order to be able to compare the impact of IFRS adoption upon the incorporation of information into stock prices. We want to see if indeed a link can be established between the adoption of International Financial Reporting Standards and stock price delay and, moreover, to establish the nature of this connection.

\section{References}

1. Armstrong, C. S., Barth, M. E., Jagolinzer, A. D., \& Riedl, E. J. (2010). Market Reaction to the Adoption of IFRS in Europe. The Accounting Review, 85(1), 31-61. http://aaajournals.org/doi/abs/10.2308/accr.2010.85.1.31?code=aaan-site

2. Arrif, M., Loh, A.L.C., \& Chew, P. (1997). The Impact of Accounting Earnings Disclosures on Stock Prices in Singapore. Asia Pacific Journal of Management, 14(1), 17-29. https://link.springer.com/article/10.1023/A:1015429012076

3. Azzali, S., Fornaciari, L., \& Mazza, T. (2013). The Value Relevance of Earning Management in Manufacturing Industries Before and During the Financial Crisis. European Journal of Accounting, Finance \& Business, $1(1), \quad 3-55$. http://www.seap.usv.ro/ lucianp/accmng/index.php?pag=showcontent \&issue=1\&year=2013 
4. Bae, K.H., Ozoguz, A., Tan, H., \& Wirjanto, T.S. (2012). Do foreigners facilitate information transmission in emerging markets? Journal of Financial Economics, 105, 209-227. https://www.sciencedirect.com/science/article/pii/S0304405X12000025

5. Ball, R., \& Brown, P. (1968). An Empirical Evaluation of Accounting Income Numbers. Journal of Accounting Research, 6(2), 159-178. https://www.jstor.org/stable/2490232?seq=1\#page_scan_tab_contents

6. Ball, R. (2001). Infrastructure Requirements for an Economically Efficient System of Public Financial Reporting and Disclosure. Brookings-Wharton Papers on Financial Services, 127169. DOI: $10.1353 /$ pfs.2001.0002

7. Barry, C., \& Brown, S. (1984). Anomalies in Security Returns and the Specification of the Market Model. The Journal of Finance, 39(3), 807-815. https://onlinelibrary.wiley.com/toc/15406261/39/3

8. Barth, M.E., Landsman, W.R., \& Lang, M.H. (2008). International Accounting Standards and Accounting Quality. Journal of Accounting Research, 46 (3), 467-498. https://onlinelibrary.wiley.com/doi/abs/10.1111/j.1475-679X.2008.00287.x

9. Bartov, E., Goldberg, S., \& Kim, M. (2005). Comparative value relevance among German, US, and International Accounting Standards: a German stock market perspective. Journal of Accounting, Auditing and Finance, 253-294. http://journals.sagepub.com/doi/10.1177/0148558X0502000201

10. Basu, S., (1997). The Conservatism Principle and the Asymmetric Timeliness of Earnings. $\begin{array}{llll}\text { Journal of Accounting and } & \text { Economics, }\end{array}$ https://www.sciencedirect.com/science/article/pii/S0165410197000141

11. Beaver, W., Kettler, P., \& Scholes, M. (1970). The Association Between Market-Determined and Accounting Determined Risk Measures. The Accounting Review, 45(4), 654-682. https://www.jstor.org/stable/244204?seq=1\#page_scan_tab_contents

12. Brennan, M. (1991). A Perspective on Accounting and Stock Prices. The Accounting Review, 66(1), 67-79. https://www.jstor.org/stable/247706?seq=1\#page scan tab contents

13. Breton, G., \& Taffler, R. (1995). Creative Accounting and Investment Analyst Response. Accounting and Business Research, 25(98), 81-92.

14. Callen, J., Khan, M., \& Lu, H. (2011). Accounting Quality, Stock Price Delay, and Future Stock Returns. Contemporary Accounting Research, 30(1), 269-295. http://doi.org./10.1111/j.1911-3846.2011.01154.X

15. Campbell, J. Y., Sanford J. G., \& Jiang W. (1993). Trading Volume and Serial Correlation in Stock Returns. The

16. Quarterly Journal of Economics, 108, 905-939. https://www.jstor.org/stable/2118454

17. Campbell, J.Y., Lo, A.W., \& MacKinlay, A.C. (1997). The Econometrics of Financial Markets. Princeton University Press, Princeton.

18. Chen, J., Dong, W., Li, S. \& Zhang, Y. (2018). Perceived audit quality, state ownership, and stock price delay: evidence from China. Asia-Pacific Journal of Accounting and Economics, 25(1-2), 253-275.

19. Clubb, C. (1995). An empirical study of the information content of accounting earnings, funds flows and cash flows. The Accounting Review, 62, 723-747. https://onlinelibrary.wiley.com/doi/abs/10.1111/j.1468-5957.1995.tb00670.x

20. Daske, H., Hail, L., Leuz, C., \& Verdi, R. (2008). Mandatory IFRS reporting around the world: Early evidence on

21. the economic consequences. Journal of Accounting Research, 46(5), 1085-1142.

22. $\quad$ https://doi.org/10.1111/j.1475-679X.2008.00306.x 
23. Dechow, P. (1994). Accounting earnings and cash flows as measures of firm performance. The role of accounting accruals. Journal of Accounting and Economics, 18, 3-42. https://doi.org/10.1016/0165-4101(94)90016-7

24. De George, E., Li, X., \& Lakshmanan, S. (2016). A review of the IFRS adoption literature. Review of Accounting Studies, 21(3), 898-1004. DOI: 10.1007/s11142-016-9363-1

25. Dima, B., \& Miloș, L.R. (2006). Testing the efficiency market hypothesis for the Romanian stock market, Oeconomica, 11(1). http://oeconomica.uab.ro/upload/lucrari/1120091/41.pdf

26. Dragotă, V., \& Mitrică, E. (2004). Emergent capital markets' efficiency: the case of Romania, European Journal of Operational Research, 353-360.

27. https://www.sciencedirect.com/science/article/abs/pii/S0377221703000936

28. Easley, D., O'Hara, M., \& Hvidkjaer, S. (2002). Is Information Risk A Determinant of Asset Returns. The Journal of Finance, 57(5), 2185-2221. https://doi.org/10.1111/1540-6261.00493

29. Easton, P., \& Harris, T. (1991). Earnings As An Explanatory Variable For Returns. Journal of Accounting Research, 29(1), 19-36. https://www.jstor.org/stable/pdf/2491026.pdf?seq=1\#page_scan_tab_contents

30. Emery, J. (1974). Efficient Capital markets and the Information Content of Accounting Numbers. The Journal of Financial and Quantitative Analysis, 9(2), 139-149.

31. https://www.jstor.org/stable/2330089?origin=crossref\&seq=1\#page_scan_tab_contents

32. Fama, E. (1970). Efficient Capital Markets, A Review of Theory and Empirical Work. The Journal of Finance, 25(2), 383-417. https://www.jstor.org/stable/2325486

33. Holthausen, R., \& Watts, R. (2001). The relevance of the value-relevance literature for financial accounting standard setting. Journal of Accounting and Economics, 31(1-3), 3-75. https://doi.org/10.1016/S0165-4101(01)00029-5

34. Hou, K., Moskowitz, T.J. (2005). Market frictions, price delay, and the cross-section of expected returns. Review of Financial Studies, 18, 981-1020. https://doi.org/10.1093/rfs/hhi023

35. Lambert, R., Leuz, C., \& Verrecchia, R. (2007). Accounting Information, Disclosure, and the Cost of Capital. Journal of Accounting Research, 45(2), 385-420. https://onlinelibrary.wiley.com/doi/abs/10.1111/j.1475-679X.2007.00238.x

36. Landsman, W. R., Maydew, E. L., \& Thornock, J. R. (2012). The information content of annual earnings announcements and mandatory adoption of IFRS. Journal of Accounting and Economics, 53(1-2), 34-54. https://doi.org/10.1016/j.jacceco.2011.04.002

37. Larson, R. \& Street, D. (2004). Convergence with IFRS in an expanding Europe, progress and obstacles identified by large accounting firms' survey. Journal of International Accounting, Auditing and Taxation, 13(2), 89-119. doi:10.1016/j.intaccaudtax.2004.09.002

38. Lim, K.P. \& Hooy, C.W. (2010). The delay of stock price adjustment to information, a country-level analysis. Economics Bulletin, 30(2), 1609-1616. http://www.accessecon.com/Pubs/EB/2010/Volume30/EB-10-V30-I2-P148.pdf

39. Lo, A. W., \& MacKinlay, A. C. (1999). A non-random walk down Wall Street. Princeton, N.J, Princeton University Press.

40. Lo, A.W. (2008). Efficient markets hypothesis. In S.N. Durlauf \& L.E. Blume (Eds.), The New Palgrave Dictionary of Economics Online (2nd edition, doi,10.1057/9780230226203.9780230220454). New York, Palgrave Macmillan.

41. Loh, A., \& Walter, T. (1986). The Relationship Between Unsystematic Security Returns and Earnings Forecast Errors. Accounting and Finance, 26(1), 13-24.

42. Merton, R. (1987). A Simple Model of Capital Market Equilibrium with Incomplete information. The Journal of Finance, 42(3), 483-510. https://doi.org/10.1111/j.1540- 


\section{$\underline{6261.1987 . t b 04565 . x}$}

43. Novak, J. (2008). On the Importance of Accounting Information for Stock Market Efficiency. Doctoral thesis. Uppsala Universitet, Uppsala. Sweden.

44. Roychowdhury, S. (2006). Earnings management through real activities manipulation. Journal of Accounting and Economics, 42, 335-370. https://doi.org/10.1016/j.jacceco.2006.01.002

45. Sato, S. \& Takeda, F. (2017). IFRS Adoption and Stock Prices of Japanese Firms in Governance System Transition. The Journal of Accounting, 52(4), 319-337. http://www.sciencedirect.com/science/article/pii/S002070631630142X

46. Stănculescu, A., \& Mitrică, E. (2012). Testing weak form informational efficiency on the Romanian capital market. Theoretical and Applied Economics, 19(9), 29-36.

47. Strong, N., \& Walker, M. (1993). The explanatory power of earnings for stock returns. The Accounting Review, 68, 385-399. https://www.jstor.org/stable/248407

48. Todea, A. (2002). The theory of efficient markets and technical analysis: the case of the Romanian market. Studia Universitatis Babeş-Bolyai Oeconomica, 1, 107-117.

49. Turki, H., Wali, S., \& Boujelbene, Y. (2017). IFRS Mandatory Adoption Effect on the Information Asymmetry: Immediate or Delayed?, Australian Accounting, Business and Finance Journal, 11(1), 55-77. doi:10.14453/aabfj.v11i1.5

50. Urquiza, F., Abad Navarro, M. \& Trombetta, M. (2012). Disclosure Strategies and Cost of Capital, Managerial and decision economics, 33(7), 501-509.https://doi.org/10.1002/mde.2562

51. Watts, R., \& Zimmerman, J. (2006). Positive Accounting Theory. Prentice-Hall Inc.

52. Yu, W. \& Wang, J. (2014). The Information Content of Stock prices, Legal Environments, and Accounting Standards, International Evidence. European Accounting Review, 24(3), 471-493.

53. Zhang, G. (2013). Accounting Standards, Cost of capital, Resource Allocation, and Welfare in a Large Economy. The Accounting Review, 88(4), 1459-1488. https://doi.org/10.2308/accr$\underline{50375}$ 